\title{
Aphid herbivory as a potential driver of primary succession in coastal dunes
}

\author{
Charlotte Van Moorleghem ${ }^{1,2} \cdot$ Eduardo de la Peña ${ }^{1,3}$
}

Received: 16 October 2015/Accepted: 22 February 2016/Published online: 10 March 2016

(C) Springer Science+Business Media Dordrecht 2016

\begin{abstract}
Herbivory is a major factor affecting both the performance and the fitness of the species composing a plant community and, ultimately, conditioning its temporal and spatial dynamics. Coastal dunes are a typical example of primary succession where different biotic and abiotic factors determine plant species occurrence; however, the effect of insect herbivory herein has remained little explored. To address this matter, we combined an observational study along a successional gradient with a greenhouse experiment to determine the occurrence and the impact of plant-aphid interactions. We focused on the species Schizaphis rufula, a widespread and abundant aphid associated with dune grasses in early stages of primary succession in Europe. Firstly, we studied aphid infestation rates on the dune grass Ammophila arenaria along a succession gradient in three locations of the North Sea coast to address the relationship between plant community composition and aphid occurrence; secondly, we tested the effect of aphid herbivory on a set of dune species typical for the different stages of succession. We found that the degree of aphid infestation was inversely correlated
\end{abstract}

Handling Editor: Robert Glinwood.

Eduardo de la Peña

e.delapena@csic.es

1 Terrestrial Ecology Unit, Department of Biology, Faculty of Sciences, University of Ghent, K.L. Ledeganckstraat 35, 9000 Ghent, Belgium

2 Laboratory for Functional Morphology, Department of Biology, Faculty of Sciences, University of Antwerp, Universiteitsplein 1, 2610 Wilrijk, Belgium

3 Institute for Mediterranean and Subtropical Horticulture "La Mayora" (IHSM-UMA-CSIC), 29750 Algarrobo-Costa, Málaga, Spain with the degree of dune fixation. The results of the experiment showed that aphid multiplication was significantly higher and its effect more pronounced on two early successional grass species, i.e. A. arenaria and Leymus arenarius. Here aphid multiplication resulted in a severe decrease in plant biomass; in late successional grass species, there was limited multiplication and no effect on biomass. The results of the field survey and the greenhouse experiment indicate that aphids show a clear preference for plants from early successional stages and, moreover, they have a greater impact on these plant species. All this supports the hypothesis of aphid herbivory as a driving factor of primary succession in coastal dunes.

Keywords Plant-insect interactions - Schizaphis rufula . Primary dune succession - Plant competition .

Aboveground herbivory $\cdot$ Host specificity

\section{Introduction}

Herbivory is a major factor affecting plant populations and community structure through detrimental effects on individual plant performance and fitness (Strauss and Agrawal 1999; Fornoni 2011). Effects of herbivory at the individual plant level have important consequences at other levels of organization, i.e. population, community and ecosystem (Borer et al. 2014; Horgan et al. 2014; Bai et al. 2012; Schmitz 2008). The main underlying mechanism is the differential impact of herbivory on different plant species. That is, insect herbivores show varying host-plant preferences; different host plants in turn show variable tolerances or resistance to the herbivores (Choeni and Sebata 2014; Ibanez et al. 2013; Kuijper et al. 2010; Strauss and Agrawal 1999). By means of such variation in herbivory and 
tolerance, herbivores determine interspecific competition and influence productivity, species diversity, evenness and composition within the community (Allan and Crawley 2011; Stein et al. 2010; Hillebrand et al. 2007; Maron and Crone 2006). Succession is a sequential change in relative abundances of the dominant plant species in a community (Huston and Smith 1987). Consequently, herbivores have the power to drive (or halt) plant succession if they influence the competitive abilities of early successional plant species relative to later successional plant species (Ibanez et al. 2013; Karlsen et al. 2013; Bach 2001).

Herbivorous insects occur in all terrestrial habitats and the extent of their impact is influenced by: (1) the amount and quality of resources, so-called bottom-up control; (2) other biotic characteristics e.g. presence of natural enemies or competitors, i.e. top-down control; (3) abiotic factors that influence their population dynamics (Stam et al. 2014; Massad 2013; Tariq et al. 2012; Vandegehuchte et al. 2010a; Jactel and Brockerhoff 2007; Unsicker et al. 2006; Bezemer et al. 2005). Plant diversity has been suggested as a key factor affecting the outcome of plant-herbivore interactions (Pimentel 1961; Root 1973). Nonetheless, its role remains debated as some authors' argument that plant diversity does not affect plant-herbivore interactions but on the contrary, it is a result of it (Stein et al. 2010). According to theory, herbivore effects are expected to be more prevalent in species-poor than in species-rich environments (Haddad et al. 2009; Root 1973). To explain this assertion, two mechanisms, that are not mutually exclusive, have been put forward: (a) increased competitive performance: herbivore specialist species present in species-poor plant communities will selectively direct herbivory towards one or a few plant species, benefitting non-host plants and allowing species replacement (Stein et al. 2010; Long et al. 2003; Root 1973); and (b) increased community complexity: the occurrence of a greater diversity of natural enemies in plant species-rich environments will result in stronger top-down control of herbivore populations, reducing their impact on the vegetation (Pimentel 1961).

Succession means the directional change in plant and animal communities with time (Connel and Slatyer 1977). Primary succession occurs on sites that have not previously been occupied by vegetation. A typical example is the development of a sand dune ecosystem, where plant species abundance and composition are determined by several interdependent processes: (1) the development of soil horizons and the decrease in sand accretion (Lichter 2000) (2) plant-soil feedbacks (de la Peña et al. 2009; Van der Stoel et al. 2002; Imbert and Houle 2001; van der Putten et al. 1989) and (3) ageing of some species (Maun 2009). All these processes affect the competing abilities of the different plant species along the succession and, hence, contribute to a plant species replacement. Herbivory in coastal dunes has been studied by addressing the impact of large herbivores (rabbits and large grazers) on late successional development (Maun 2009). For the particular case of insect herbivores, their role has been studied in species-rich habitats of inner dunes or in secondary succession (Bach 1994, 2001). For early dune seral stages, the literature mainly covers the role of (a)biotic soil factors, while insect herbivory has so far been overlooked (Vandegehuchte et al. 2010a; Maun 2009; Van der Stoel et al. 2002; Bach 2001). Nonetheless, the relative abundances of some functional groups associated with early successional species suggest that herbivory is an important factor for the plant community.

Coastal dunes are extreme environments, where both plant and animal species have to deal with several environmental stresses such as sand accretion, salt spray, extreme temperature variability, wind, etc. (Huiskes 1979). Because of such extreme conditions, dunes harbour a very specialized insect community. Sampling surveys have shown a diverse array of insect herbivores belonging to different functional guilds (Vandegehuchte et al. 2010a; Nickel and Rename 2002). The aphids Schizaphis rufula (Walker, 1849), Rhopalosiphum padi (Linnaeus, 1758) and Laingia psammae (Theobald, 1922) are common species in European dunes. While the two latter species are present in other types of grasslands, Schizaphis rufula (Walker, 1849) is only found in dunes where, given the high densities reached at some sites, its presence probably has important consequences for the functioning of the dune system. From laboratory observations, we know that this aphid species reproduces easily on young Ammophila arenaria shoots (Vandegehuchte et al. 2010a), but the factors underlying their ecology and population dynamics in the field remain largely unexplored (de la Peña et al. 2014).

In this study we investigated the relationship between plant community attributes and the occurrence of S. rufula in different stages of early primary succession and, secondly, we addressed the impact of $S$. rufula on the performance of different species characteristic of different stages of succession experimentally. We had two working hypotheses. If there was no direct link between the occurrence of $S$. rufula and the type of vegetation in the field, it would suggest that there is no relationship between dune succession and aphid densities. Secondly, in order to infer a further role of aphids on plant performance and primary succession, there should be differential performance and preference of the aphids for species characteristic of early successional stages.

\section{Materials and methods}

\section{Coastal dunes and primary succession}

We focused on embryonic dunes, yellow dunes and transitional zones towards scrub encroachments to cover the 
three main seral stages of primary succession in North Sea dunes (Fig. 1). For an elaborate description of dune habitats in the region we refer to Huiskes (1979) but in short: at the North Sea, embryonic dunes are formed when sand is captured on the high beach by Elymus farctus (Crevits 2008; Bertels et al. 2005) (Fig. 2), a salt-tolerant species that stands moderate burial by vertical spread of its rhizomes. As embryonic dunes are formed and salt levels decrease, other grasses appear; mainly $A$. arenaria and, to a much lesser extent and confined to frontal fore-dunes, Leymus arenarius (Bond 1952; Clark 1964; Huiskes 1979). When large masses of sand begin to accumulate and freshwater is present in the underground, the dunes become dominated by Ammophila arenaria and are commonly referred to as yellow dunes. This grass species has a more developed system of vertically growing rhizomes which allows it to prevail on large sand masses (Huiskes 1979). When sand is not fixated entirely by A arenaria, large quantities of sand can still be relocated by wind. This subhabitat of a yellow dune is called a mobile dune habitat (also called dynamic or shifting dune habitat). The more sand gets fixated by A. arenaria, the more plant species that are not adapted to dynamic conditions settle, e.g. Festuca rubra and Carex arenaria (Huiskes 1979) and plant coverage gets gradually more species-rich. Dune scrub represents a late successional sere dominated by either Hippophae rhamnoides or Calamagrostis epigejos depending on local soil conditions, water levels and management (Bertels et al. 2005). These are also commonly referred to as grey dunes.

The genus Schizaphis (Hemiptera: Aphidoidea) comprises mainly grass inhabiting aphids of which some are of economic importance (Evidente et al. 2009; Pettersson 1971a, b; Börner and Heinse 1957). Schizaphis rufula (Walker, 1849) can be found across European coastal dunes with observations in Scandinavian countries i.e. Finland, Sweden and Denmark and also in more southern regions such as Corsica and Sicily. In central and western Europe, it is known to occur in Germany, Poland, the Netherlands, Britain, Ireland and more recently it has been observed in Belgium (Vandegehuchte et al. 2010b; Nieto Nafría 2007). The late discovery of $S$. rufula in Belgium is most likely due to previous limited sampling surveys in Belgian dunes, rather than being an introduced species.

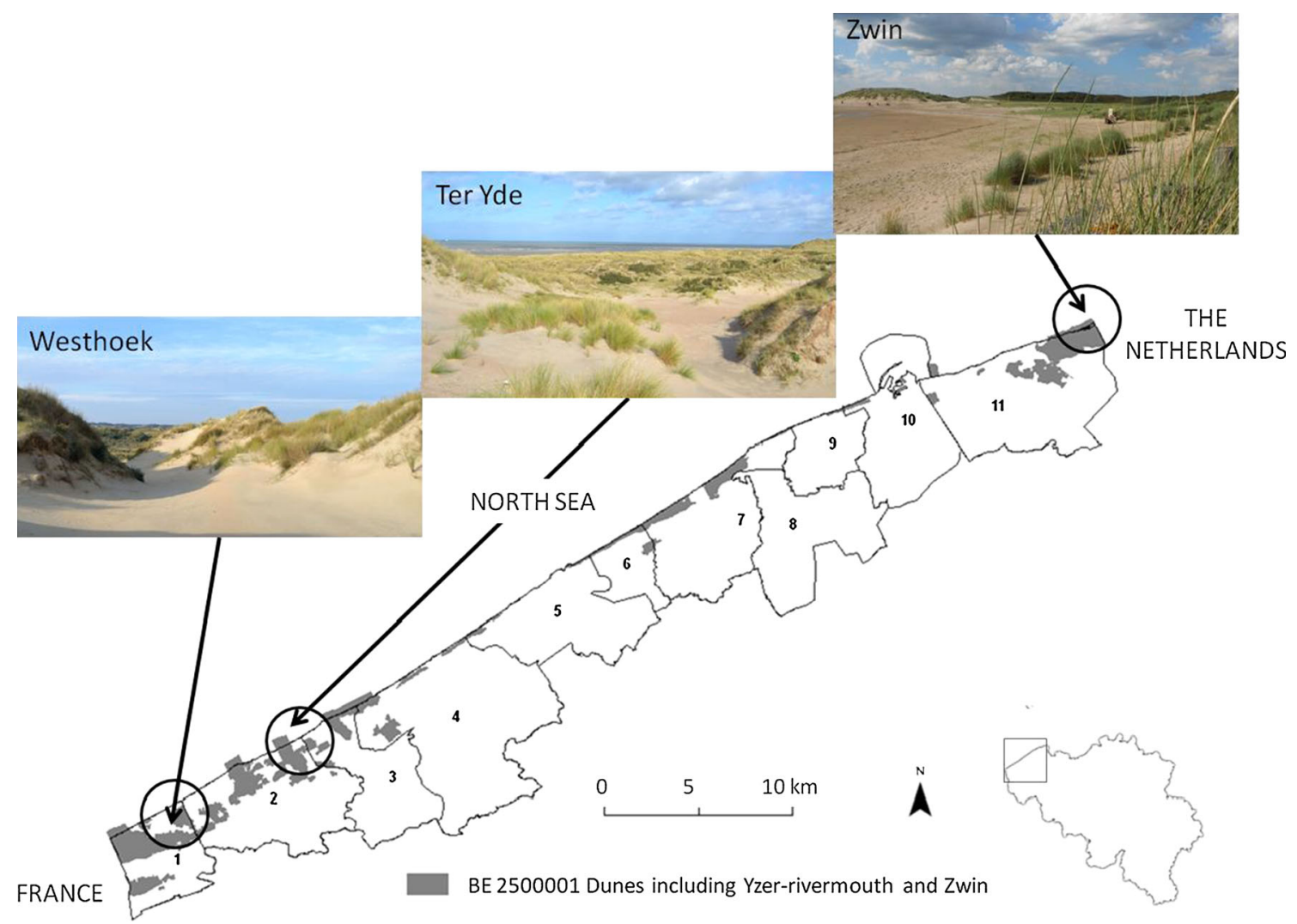

Fig. 1 Location of the study sites for the field survey. The three locations (encircled) are indicated on a map of Belgian dune sites of community importance in the EU Natura 2000 network $(1=$ De Panne (Westhoek), 2 = Koksijde (Ter Yde), 3 = Nieuwpoort,
$4=$ Middelkerke, $5=$ Oostende, $6=$ Bredene, $7=$ De Haan, $8=$ Zuienkerke, $\quad 9=$ Blankenberge, $\quad 10=$ Zeebrugge, $11=$ Knokke-Heist (Het Zwin)) (adapted from Herrier et al. 2005) 


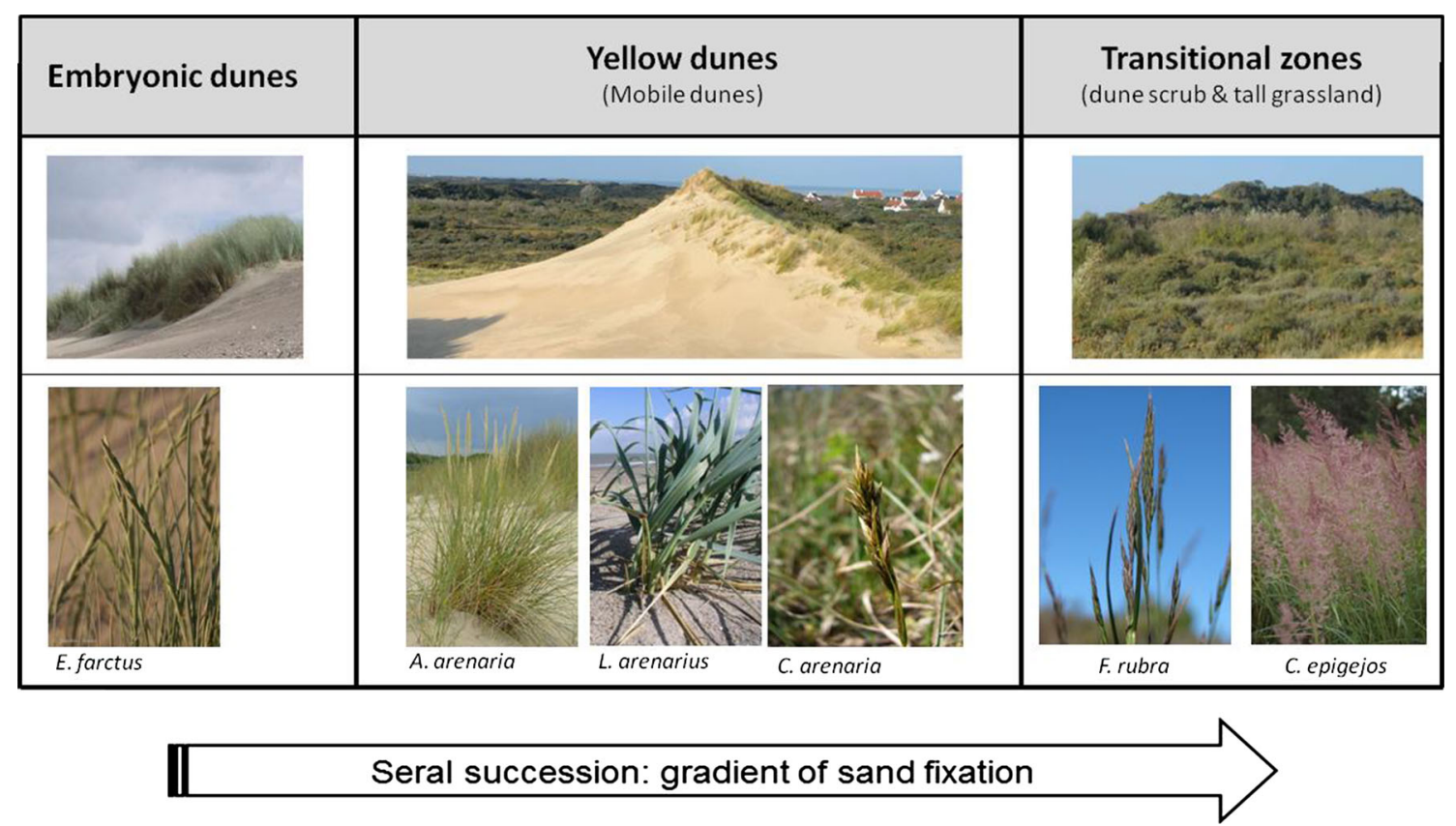

Fig. 2 Schematic representation of the grass and sedge species replacement along the dune seral succession. From left to right, representing the natural gradient from embryonic to grey (fixed) dunes appear: Elymus farctus as a representative of embryonic dunes,

This is also supported by the fact that the aphid is known to be native to the Dutch coastal region, which is similar to the Belgian one (Weeda et al. 2003). It can be found from early spring until October feeding and reproducing on dune grasses including A. arenaria, E. farctus and $L$. arenarius. Like most other aphid species, S. rufula has two ways of reproducing; sexual reproduction, in which eggs are laid (oviparity), and asexual or parthenogenetic reproduction where offspring is produced in a viviparous way (Turpeau et al. 2013). Parthenogenetic reproduction is the main reproduction method during the year, and many generations are produced as such. Offspring are thus clones of the mother and mainly comprise wingless aphids. Sexual reproduction occurs when temperatures and day-length decline during autumn. Eggs that are laid after sexual reproduction are a means to survive under unfavourable winter conditions and are regarded as a diapause stage.

\section{Study sites}

Three nature reserves were selected, two at the Belgian coast, i.e. Westhoek in De Panne and Ter Yde in Oostduinkerke and a third site at the Dutch coastline, i.e. Het Zwin-Retranchement just at the Belgian-Dutch border (Fig. 1). These three sites are included in the Natura 2000 network and have been designated as Sites of Community Importance (Herrier et al. 2005) as they comprise dune
Leymus arenarius, Ammophila arenaria and Carex arenaria in yellow dunes, with the latter species and Festuca rubra occurring in the transition towards fixated dunes; Calamagrostis epigejos is situated in tall grassland

areas where the different seral stages of primary succession are present (Provoost et al. 2011a, b).

\section{Sampling survey}

The field survey was performed in July and August 2012. At this moment of the growth season, aphid densities are usually reaching their peak (Vandegehuchte et al. 2010a). In each of the three reserves, we identified areas where vigorous sand accretion occurs, and therefore grasses of early successional stages are present, but close to areas with shrub encroachments and late successional grass species. At each site, we selected twenty individuals of $A$. arenaria separated at least $15 \mathrm{~m}$ from each other, marked them with numbered flags and took their GPS-coordinates in order to find back easily each individual plant in the weeks that followed. We decided to focus on only one plant species, because in preliminary studies it had been shown to be a common host plant in the three study sites (Vandegehuchte et al. 2010a) and to facilitate comparisons along the succession gradient as this is the only grass species found from embryonic dunes (when containing salt levels below $1 \%$ ) until grey dunes (Huiskes 1979). For each marked plant, we measured the relative occurrence of bare soil (percentage of sand cover) and recorded plant species composition within a radius of one metre prior to the sampling survey. Also, general plant features were noted, i.e. length of the largest leaf, diameter of the tussock 
and number of leaves. On each of these plants, the amount of $S$. rufula individuals was determined by inspecting each leaf and then making the total count per plant individual. These aphids do not tend retract their rostrum from the leave if not strongly disturbed; therefore, a careful handling of the leaves did not affect the amount of aphids on the plant. This was done on a weekly basis for a period of 4 weeks.

\section{Experimental assessment of impact of aphid herbivory on grasses}

For this green-house experiment, we selected species representative of different successional seres: E. farctus for embryonic dunes, L. arenarius for the transition between embryonic and yellow dunes, A. arenaria for yellow dunes, $F$. rubra and Carex arenaria L. for fixed dunes and Calamagrostis epigejos as late successional species characteristic of humid fixed grey dunes. Seeds of E. farctus, A. arenaria, $C$. arenaria, $F$. rubra, and $C$. epigejos were collected in the nature reserve Westhoek in De Panne, Belgium, whereas seeds of $L$. arenarius originated from nature reserve Het Zwin in Retranchement, the Netherlands. All seeds were first subjected to surface sterilization by washing the seeds in $30 \%$ Ethanol for $2 \mathrm{~min}$, then in $10 \%$ bleach for $5 \mathrm{~min}$ and finally rinsing with abundant sterile $\mathrm{dH}_{2} \mathrm{O}$. After this treatment, seeds were kept overnight in a sufficient amount of distilled water to soak and remove any bleach residues and then they were plated onto petri dishes containing a $1 \%$ water agar. Petri dishes were then left on a laboratory bench exposed to the natural night/day photoperiod. When seeds germinated, seedlings were planted in polypropylene $250-\mathrm{mL}$ cups filled with sterilized sand collected in the dunes of the Westhoek. Sterilization (by autoclaving $2 \mathrm{~h}$ at $1.2 \mathrm{~atm}$ ) of the sand is necessary to eliminate a potential effect of soil biota on the response of plants to herbivores (Vandegehuchte et al. 2010a, b, c, Vandegehuchte et al. 2011). For five weeks, plants were maintained under fluorescent lamps in a growth chamber with a summer night/day regime of $8 / 16 \mathrm{~h}$ and day temperatures reaching $22 \pm 2{ }^{\circ} \mathrm{C}$. Based on previous experimental set-ups using dune grasses and $S$. rufula and also supported by the preliminary observations of Pettersson (1971c), 5-6 weeks is the plant age that allows optimal feeding by these aphids. So after five weeks experimental plants were treated with aphids that have been previously maintained in culture in the laboratory. Schizaphis rufula individuals taken from nature reserve Westhoek in De Panne, Belgium, were reared in the laboratory on $A$. arenaria plants under the same conditions as the re-potted plants. The experiment compared the performance of $S$. rufula, measured as aphid multiplication and aphid persistence on the compared plant species, as well as the performance of plants with or without aphids measured in terms of biomass production. On each experimental plant, a single adult female of $S$. rufula obtained from a previously established aphid culture was placed. The number of replications for each species per treatment (experiment $v s$. control) was as follows: E. farctus $(7 / 11)$, A. arenaria (10/11), L. arenarius (10/10), F. rubra $(6 / 10)$ and $C$. epigejos $(5 / 5)$. The variation in the number of replication for some plant species responds to a high mortality after transplantation for some plant species (i.e. C. epigejos). To prevent aphids from escaping, plastic chambers were placed over each plant individual. The number of aphids on experimental plants was counted every other day. Once a week experimental pots were randomly repositioned under the fluorescent lamps. After 4 weeks, plants were harvested and plant dry weight was determined after putting all plants for $24 \mathrm{~h}$ in an oven set to $60{ }^{\circ} \mathrm{C}$.

\section{Statistical analysis}

Statistical analyses were conducted using the statistical package SAS $^{\circledR}$ version 9.4 (SAS Institute Inc., Cary, NC, U.S.). Models were built based on sequential removal of variables with non-significant Wald statistics (SAS Institute Inc. 2014). Generalized linear mixed models (GLMM) were used when not otherwise indicated. For the field survey, a correlation matrix was made to prevent setting covariant variables together in the predictive models. Plant characteristics, i.e. tussock diameter, length and number of leaves and other environment-related variables, i.e. species richness, sand cover, etc. were analysed separately. Richness (R), which is the number of plant species within a one metre radius from the studied plant individual, was calculated (Colwell 2009). Location (Westhoek, Ter Yde and Zwin) and plant individual (1-60) were included as random factors in all models. Because surveyed plants were measured on different occasions in the course of the survey, date was included as a random factor nested within plant individual. For aphids we took three variables: (1) presence or absence of $S$. rufula on plants, implemented in the statistical models as a variable with binomial random structure, (2) aphid abundance and (3) relative aphid abundance (number of aphids divided by the number of leaves of the tussock). The latter two measures were put in the models as being Poisson distributed. For these three variables, it was assessed which plant and environmental characteristics better predicted aphid occurrence. Plant individuals that had no aphids were left out of the analyses regarding relative and absolute aphid abundances.

To determine whether plant identity had a significant impact on $S$. rufula population build-up in the green-house experiment, aphid abundance per species and the number 
of days that aphids persisted on the plants were used in a generalized mixed linear model analysis. Persistence was defined as the amount of days that the aphid stayed alive on a plant (even without reproduction). A Tukey's test was performed for pairwise comparisons among plant species. The impact of $S$. rufula on plant biomass was assessed by comparing the dry weight of control and aphid-treated plants.

\section{Results}

\section{Field survey}

The number of aphid infested $A$. arenaria plants varied according to different environmental characteristics (Table 1). Aphid infestation was negatively correlated with the percentage of $F$. rubra $\left(F_{1,68.19}=11.92, P=0.0010\right)$ and also with plant species richness $\left(F_{1,95.98}=21.10\right.$, $P<0.0001)$. The percentage of sand cover, on the other hand, was positively correlated with infestation rate $\left(F_{1,55.23}=4.79, P=0.0328\right)$. Regarding plant characteristics, the more leaves the plant had $\left(F_{1,53.82}=5.34\right.$, $P=0.0247)$ and the higher it was $\left(F_{1,53.65}=6.52\right.$, $P=0.0135)$, the higher the chance to encounter $S$. rufula feeding on the plant. However, the relative abundance of aphids (that is correcting the total number of aphids by the number of leaves) was determined by tussock diameter $\left(F_{1,93}=6.29 ; P=0.0139\right)$ and height $\left(F_{1,89.77}=4.63\right.$; $P=0.0341)$; both negatively correlated with aphid number. Therefore, smaller plants harboured more aphids relative to their size than large plants.

\section{Experimental assessment of impact of aphid herbivory on grasses}

Aphid abundances differed between the species compared $\left(F_{5,1}=962.05 P=0.0245\right)$. Aphid abundance was significantly higher on $A$. arenaria and $L$. arenarius than on the rest of the plant species (Fig. 3). For L. arenarius aphid densities reached at their peak a daily average of ca. 60 individuals, while for $A$. arenaria average densities never reached above 30 . For the rest of the grass species, aphid multiplication, as seen from the change in abundances over time, was observed in some species but almost never reached values beyond 10 individuals. When taking $L$. arenarius and $A$. arenaria out of the analyses, no differences are found between the compared species $\left(F_{3,1}=39.91, P=0.1157\right)$.

Similarly, aphid persistence depends on plant species $\left(F_{5,51}=44.67, P<0.0001\right.$; Fig. 4$)$ and it was again significantly higher on the $L$. arenarius and $A$. arenaria, with no significant differences between the two $\left(t_{77}=-1.03\right.$,
$P=0.3065)$. These results demonstrate that these dune grasses are the most suitable host plants for this aphid species.

Furthermore, a significant decrease in biomass in aphidtreated plants (dry weight) was only observed for these two species, even if we corrected for aphid numbers (A. arenaria: $t_{18}=4.43, P=0.0003 ;$ L arenarius: $t_{18}=3.29$, $P=0.0041$; Fig. 5). This shows a higher susceptibility or lack of tolerance of these species towards the aphid.

\section{Discussion}

By means of an observational field survey, we addressed $S$. rufula abundance on $A$. arenaria in different stages of primary succession. Furthermore, we studied experimentally the impact of aphid herbivory on the performance of grasses characteristic of early stages of succession. The field survey shows that $S$. rufula is mainly found on its $A$. arenaria when this is growing on sites with environmental conditions characteristic of mobile yellow dunes (i.e. low species richness, high percentages of bare sand). The aphid infestation rate decreased when plant diversity and the density of $F$. rubra, both indicators of increasing levels of dune fixation, increased. The analysis of basic traits for the surveyed $A$. arenaria stands reveals an inverse relationship between tussock size (i.e. tussock diameter, number of leaves and length) and aphid relative abundance, indicating a preference of this aphid species for young plant stands. The experimental study clearly indicates that aphid (parthenogenetic) reproduction occurs mainly on the grass species present in (semi-)mobile yellow dunes, i.e. $A$. arenaria and L. arenarius, while for the other species the aphid could survive but had limited reproduction. Note that this is also the case for E. farctus, the earliest pioneer species in dune succession. Moreover, aphid herbivory only had a negative impact (by drastically reducing plant biomass) on plants occurring in yellow dunes. The results of the survey and the experiment demonstrate that $S$. rufula is detrimental to key grass species in yellow dunes and accordingly; it should be considered as a key element to understand early stages of dune succession.

The role of plant diversity on herbivory remains disputed as some authors' argument that plant diversity is a factor driving herbivory while others say it is a result of it (Pimentel 1961; Root 1973; Stein et al. 2010). The predictive models obtained in our survey show an inverse correlation between infestation rate and plant diversity. If aphid herbivory would not be relevant for the dynamics of the plant community, there would be no differences in infested plants along the succession and moreover, the impact on different grass species along the succession would be negligible. Our results therefore suggest that the 
Table 1 Statistics for the generalized linear mixed models addressing aphid occurrence (presence/absence) and relative abundance (no. of aphids/no. of leaves) in the field as a function of different predictive variables i.e. sampling location, environmental characteristics within a $1 \mathrm{~m}$ radius of the surveyed Ammophila arenaria plants and plant traits.

Significant $P$-values for the predictors are indicated in bold

\begin{tabular}{|c|c|c|c|c|c|c|}
\hline Dependent variables and predictors & Num DF & Den DF & $F$ & $\operatorname{Pr}>F$ & Intercept & Slope \\
\hline \multicolumn{7}{|l|}{ Aphid occurrence } \\
\hline \multicolumn{7}{|l|}{ Predictors (random effect) } \\
\hline Sampling location & 2 & 52.85 & 4.78 & 0.0124 & - & - \\
\hline \multicolumn{7}{|c|}{ Predictors (environment in $1 \mathrm{~m}$ radius) } \\
\hline Festuca rubra & 1 & 68.19 & 11.92 & 0.001 & 0.2982 & -0.4701 \\
\hline Ammophila arenaria & 1 & 48.61 & 0.26 & 0.6147 & -0.7054 & 0.01315 \\
\hline Elymus farctus & 1 & 46.84 & 0.38 & 0.5381 & -0.6114 & 0.04375 \\
\hline Carex arenaria & 1 & 150 & 1.65 & 0.2014 & -0.4619 & -0.2474 \\
\hline Percentage of sand & 1 & 55.23 & 4.79 & 0.0328 & -4.1481 & 0.044 \\
\hline Species richness & 1 & 95.98 & 21.1 & $<0.0001$ & 2.163 & -1.0221 \\
\hline \multicolumn{7}{|l|}{ Predictors (plant traits) } \\
\hline No. of leaves & 1 & 53.82 & 5.34 & 0.0247 & -1.0732 & 0.0112 \\
\hline Length & 1 & 53.65 & 6.52 & 0.0135 & -2.5175 & 0.03868 \\
\hline Tussock diameter & 1 & 55.22 & 0.76 & 0.3867 & -0.7052 & 0.01521 \\
\hline \multicolumn{7}{|l|}{ Relative aphid abundance } \\
\hline \multicolumn{7}{|l|}{ Predictors (random effect) } \\
\hline Sampling location & 2 & 71.39 & 2.47 & 0.0917 & - & - \\
\hline \multicolumn{7}{|c|}{ Predictors (environment in $1 \mathrm{~m}$ radius) } \\
\hline Festuca rubra & 1 & 82.16 & 0.21 & 0.6454 & -1.2058 & 0.07636 \\
\hline Ammophila arenaria & 1 & 74.74 & 0.78 & 0.3799 & -0.8485 & -0.0255 \\
\hline Elymus farctus & 1 & 58.74 & 0.22 & 0.6377 & -1.1979 & 0.03063 \\
\hline Carex arenaria & 1 & 94 & 0.02 & 0.9004 & -1.1351 & -0.0476 \\
\hline Percentage of sand & 1 & 94 & 0.7 & 0.4049 & -2.8901 & 0.02074 \\
\hline Species richness & 1 & 81.2 & 0 & 0.9705 & -1.1647 & 0.01027 \\
\hline \multicolumn{7}{|l|}{ Predictors (plant traits) } \\
\hline No. of leaves & 1 & 94 & 9.41 & 0.0028 & -0.2201 & -0.0206 \\
\hline Length & 1 & 89.77 & 4.63 & 0.0341 & 0.5498 & -0.0326 \\
\hline Tussock diameter & 1 & 93 & 6.29 & 0.0139 & -0.5376 & -0.0687 \\
\hline
\end{tabular}

Radius or plant traits of the surveyed Ammophila arenaria plants

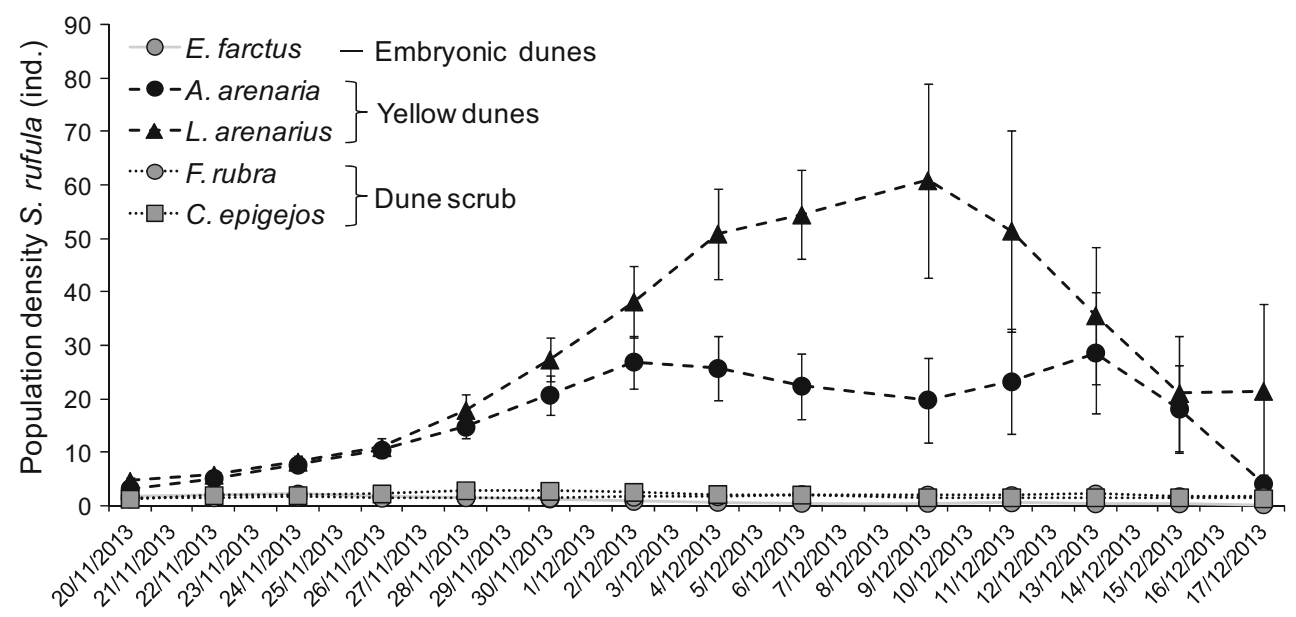

Fig. 3 Population build-up of $S$. rufula (mean number of aphids \pm SE) on different dune experimental plants. Carex arenaria was not included in the graph as there was neither aphid reproduction nor survival 
Fig. 4 Persistence or mean survival (mean $\pm \mathrm{SE}$ ) of Schizaphis rufula on experimental plants. Letters situated above each bar illustrate differences according to a Tukey's test comparing mean persistence between plant species. Same letters show no significant differences in aphid persistence
Fig. 5 Dry weight (mean \pm SE) of control and aphid-treated plants. The asterisk indicates a significant difference $(P<0.05)$ between the mean dry weight of the control and aphid-treated plants
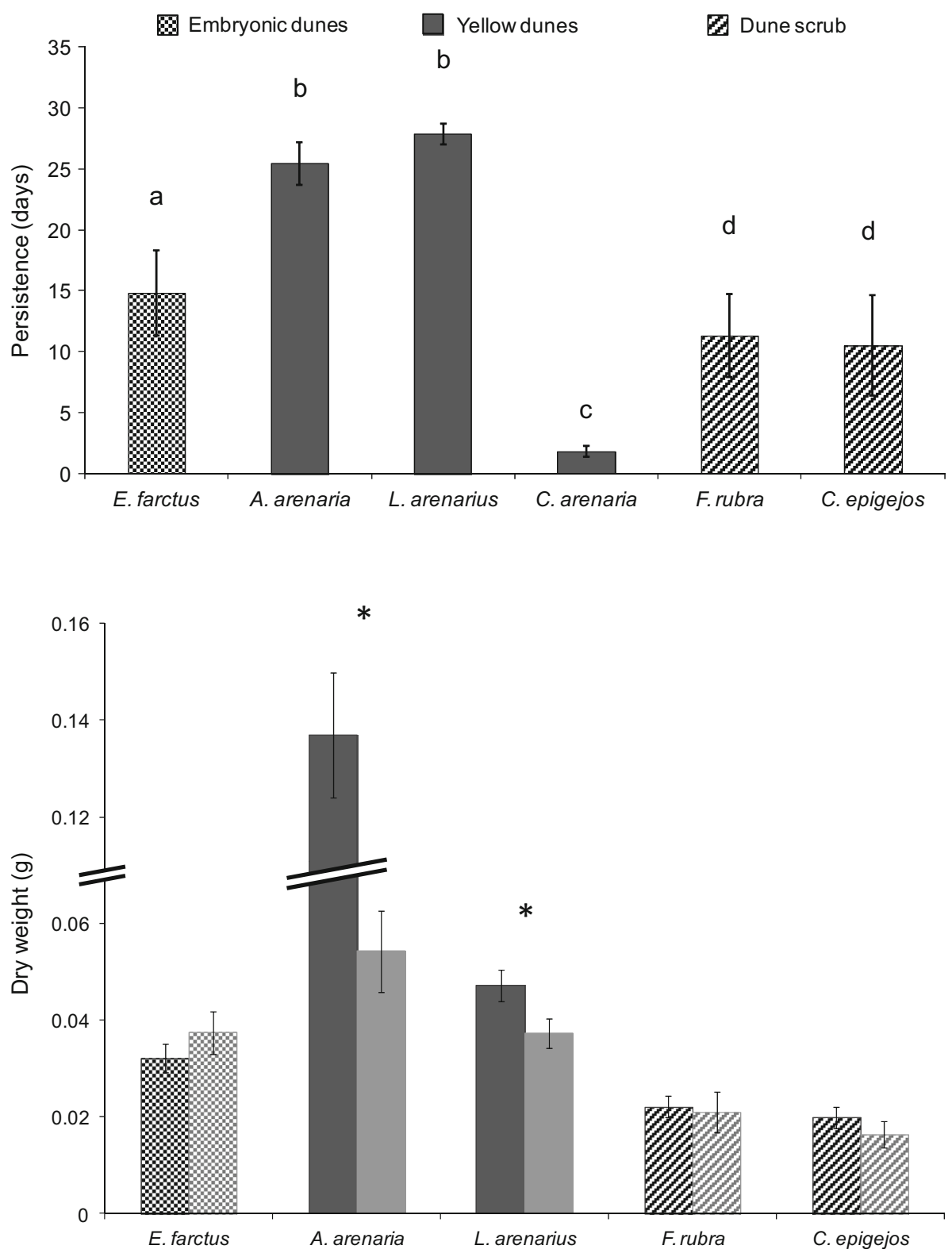

increase in plant diversity is the result of herbivory (together with other acting factors) rather than plant diversity per se and hence, herbivory should be considered as a driver, speeding up succession, and not slowing down the process in semi-mobile dunes (Connel and Slatyer 1977; Fraser and Grime 1999). With this, the effect of aphid herbivory complements the role of abiotic factors in the early successional stages. In the strandline and embryonic dunes, salinity levels prevent $A$. arenaria from outcompeting $E$. farctus (Huiskes 1979). When salt levels decrease as a consequence of dune development, $A$. arenaria becomes the dominant species and succession proceeds towards yellow dune vegetation where Schizaphis rufula can become a driver of further dune succession.
In this study, we did not address the effect of herbivory on the field (i.e. by excluding herbivores of experimental plants) (Bach 2001) and therefore, it is difficult to draw conclusions on the exact mechanisms driving species replacement due to aphid herbivory in yellow dunes. The field survey showed that aphids prefer young tussocks of $A$. arenaria (Vandegehuchte et al. 2010b), and under experimental conditions, they also have a significant impact on their growth. Accordingly, these aphid specialists contribute to plant interspecific competition by affecting a limited amount of plant species within the establishing plant community. Based on the preference for young plants, we hypothesize that aphid herbivory will mainly impact plant-recruitment either by limiting the growth of $A$. 
arenaria and $L$. arenarius seedlings or, more frequently, in mobile areas (yellow dunes), by impacting the growth of new shoots stemming out of mature plants of these species. Aphid herbivory probably affects both phases of plant development i.e. young seedlings and new shoots of mature tussocks; however, the latter situation is the one that facilitates grass species replacement. Seed germination and seedling establishment is limited to humid dune slacks (Huiskes 1979; Maun 2009). In mobile yellow dunes, establishment out of seeds for these two species is a rather rare event and therefore, colonization of new dune patches is mainly driven by clonal growth (Van der Stoel et al. 2002; Huiskes 1979). Consequently, a loss in biomass production of the grass species due to aphid herbivory on young shoots will affect competition with other dune grasses and on the long term will gradually conduct to a species replacement.

Although large plants have a higher chance to be encountered by passively or actively dispersing aphids (Vandegehuchte et al. 2010b), the highest relative abundances were found in small tussocks. This is in line with early experiments on Schizaphis species (S. rufula among others) which concluded that these aphids feed and reproduce optimally on young grass seedlings, preferably five to six weeks of age (Pettersson 1971a). Taken together, results imply: (1) resource effects (Root 1973): insects are more likely to remain and reproduce on patches with suitable host plants; (2) nutritional preferences: the nutritional value of the host-plant changes with plant age; hence, mature $A$. arenaria tussocks are of lower nutritional values and yield lower multiplication rates than young tussocks.

For dune systems, the understanding of the factors driving primary succession has been considered from different points of view: initially soil abiotic factors and in particular, the development of soil horizons and the associated occurrence of abiotic gradients e.g. salinity, nitrogen and phosphorus were thought to be the key elements driving plant species replacement (Maun 2009; Bach 2001). In the mid-1990s and early 2000s, the focus was laid on biotic soil characteristics and how soil-borne pathogens and plant-soil feedbacks would determine the competing abilities of dune plants and by doing so contribute to shifts in plant composition (Van der Stoel et al. 2002; de la Peña et al. 2006, 2009). Our results do not go against previous studies but rather complement them. Abiotic factors like salinity are probably the main factors controlling the initial phases of dune succession as pointed above (Huiskes 1979). In yellow dunes biotic factors, both above and below ground, become more important. Van der putten and Troelstra (1990) demonstrated that a complex of soil-borne organisms accumulates in the rhizosphere of $A$. arenaria in dunes. It was then shown that windblown sand in mobile dunes provides $A$. arenaria escape from these soil pathogens (De Rooij-van der Goes 1995). The results of this pioneer research show that soil-borne pathogens and the resulting plant-soil feedbacks contribute to plant species replacement in coastal dunes (Van der Stoel et al. 2002, 2006). Recent research also shows a clear specificity of certain nematode taxa for different plant species occurring at different stages of the dune succession suggesting that nematodes are actively contributing to this process (Brinkman et al. 2005 and Brinkman et al. 2015). Our results performed with only one aphid species shows a similar phenomenon occurring aboveground. Nonetheless further studies including several taxa and functional groups should be conducted. Apart from this, previous research in field and laboratory experiments indicates interactive effects between root-feeding nematodes and aboveground herbivory (Vandegehuchte et al. 2010a, c). Therefore, the role of above- and below-ground interactions in plant succession should be examined.

A remarkable result other than the impact of aphid herbivory on the grass species characteristic of yellow dunes is the ability of other species to serve as host plants. Previous experiments and observational studies have indicated $S$. rufula feeding and reproducing on $F$. rubra (Pettersson 1971c; de la Peña et al. 2014). Mummies, i.e. aphids parasitized by wasps, are often found on $F$. rubra and $C$. arenaria, suggesting that this aphid establishes in natural conditions on these host plants. In our experiment, C. epigejos, F. rubra and $E$. farctus allowed aphid persistence for relatively long periods of time (i.e., $10.5 \pm 4.11,11.3 \pm 3.4$ and $14.8 \pm 3.48$ respectively), which indicates that aphids can still retrieve a sufficient amount of nutrients from these plants for their survival. According to the phenology of $A$. arenaria, April is the month in which seed germination and shoot growth is initiated; plants are physiologically active in May and June (Huiskes 1979). Because S. rufula prefers young shoots (Pettersson 1971c), the aphid could be forced towards other dune grass species when shoots of $A$. arenaria are not yet available, that is, earlier in the year. These other dune grasses, such as $F$. rubra, could thus function as a kind of reservoir from which the aphids emerge when shoots of the more suitable host plants are present. If this is the case, then this implies that $S$. rufula could be considered a dioecious species and switches host plants over generations during the year.

Interactions in the field are complex compared to those under laboratory conditions. From the results obtained in our study, we seem to assume a completely bottom-up regulation of aphid populations in the field. However, additional factors such as predation, physical stress caused by abiotic conditions and other biotic factors associated with plants (e.g. fungal endophytes) have to be taken into account to understand aphid dynamics along the succession (Kaplan et al. 2011; Vandegehuchte et al. 2010c; van Veen 
et al. 2006). From literature and through field observations, we know Syrphid larvae and Coccinellidae predate on the aphids, but it is expected that also other generalist predators, like spiders (Araneae), occasionally feed on S. rufula (Pettersson 1971b). Moreover, in many aphid species, parasitoid wasps play an important role in controlling local populations (Hågvar and Hofsvang 1991; Starý 1987). Field observations of parasitism by at least five parasitoid hymenopterans are described in Van Moorleghem (2014; unpublished data). Therefore, there is a diverse parasitoid and predator community which could limit herbivore effects of $S$. rufula on its host plants.

\section{Conclusions}

Infestation rates by the aphid $S$. rufula on its host plant $A$. arenaria were mainly influenced by environmental factors that correlate with the degree of dune fixation. Relative aphid numbers in the field were inversely correlated with plant size, which probably confirms previous observations of aphid preference for young and physiologically active dune plant stands of early successional species. Experimental evidence demonstrated that aphid multiplication caused significantly higher densities on the early successional grass species i.e. A. arenaria and L. arenarius, characteristic of yellow dunes. Similarly, aphid herbivory had a negative effect on plant growth, while in late successional grass species there was limited multiplication and no effect on plant biomass. Given the wide distribution of this aphid species in European dunes, its high abundances in the field and the potential to impact plant growth in experimental conditions, aphid herbivory, and by extension, insect herbivory should be considered as a factor exerting community-wide effects and determining primary succession in these habitats.

Acknowledgments Eduardo de la Peña thanks the support of the Ramón y Cajal programme (RYC-2012-10254, Spanish Ministry of Economy and Competitiveness. This study was also supported by the programme Europa Investigación 2015 (EUIN2015-62833). We thank the Nature Reserve Westhoek, and all the staff at the Terrestrial Ecology group of Ghent University and Eline Vermote for their help during the course of this study and two anonymous reviewers for their helpful comments on the manuscript. We thank Prof. Jan Pettersson for sending to us his original works on the genus Schizaphis.

\section{References}

Allan E, Crawley MJ (2011) Contrasting effects of insect and molluscan herbivores on plant diversity in a long-term field experiment. Ecol Lett 14:1246-1253. doi:10.1111/j.1461-0248. 2011.01694.x
Bach CE (1994) Effects of a specialist herbivore (Altica Subplicata) on Salix cordata and sand dune succession. Ecol Monogr 64:423-445

Bach CE (2001) Long-term effects of insect herbivory and sand accretion on plant succession on sand dunes. Ecology 82:1401-1416

Bai Y, Wu J, Clark CM, Pan Q, Zhang L, Chen S, Wang Q, Han X (2012) Grazing alters ecosystem functioning and C:N: P stoichiometry of grasslands along a regional precipitation gradient. J Appl Ecol 49:1204-1215. doi:10.1111/j.1365-2664. 2012.02205.x

Bertels L, Deronde B, Kempeneers P, Provoost S, Tortelboom E (2005) Potentials of airborne hyperspectral remote sensing for vegetation mapping of spatial heterogeneous dynamic dunes-a case study along the Belgian coastline. In: Herrier J-L, Mees J, Salman A, Seys J, Van Nieuwenhuyse H, Dobbelaere I (eds) Proceedings 'Dunes and Estuaries 2005'-international conference on nature restoration practices in European coastal habitats. Koksijde, Belgium, pp 153-163

Bezemer TM, De Deyn GB, Bossinga TM, Van Dam NM, Harvey JA, van der Putten WH (2005) Soil community composition drives aboveground plant-herbivore-parasitoid interactions. Ecol Lett 8:652-661. doi:10.1111/j.1461-0248.2005.00762.x

Bond TET (1952) Biological flora of the British Isles: Elymus arenarius L. J Ecol 40:217-227

Borer ET, Seabloom EW, Mitchell CE, Cronin JP (2014) Multiple nutrients and herbivores interact to govern diversity, productivity, composition, and infection in a successional grassland. Oikos 123:214-224. doi:10.1111/j.1600-0706.2013.00680.x

Börner C, Heinse K (1957) Aphidina-Aphidoidea. In: Sorauer P (ed) Handbuch der Pflanzenkrankheiten, 5th edn. Paul Parey, Berlin, pp $1-402$

Brinkman EP, Duyts H, van der Putten WH (2005) Consequences of variation in species diversity in a community of root-feeding herbivores for nematode dynamics and host plant biomass. Oikos 110:417-427

Brinkman EP, Duyts H, Karssen G, van der Stoel CD, van der Putten WH (2015) Plant-feeding nematodes in coastal sand dunes: occurrence, host specificity and effects on plant growth. Plant Soil 397:17-30. doi:10.1007/s11104-015-2447-z

Choeni H, Sebata A (2014) Interspecific variation in the resprouting responses of Acacia species following simulated herbivory in a semi-arid southern African savannah. Afr J Ecol 52:479-483. doi:10.1111/aje.12149

Clark LR (1964) The population dynamics of Cardiaspina albitextura (Psyllidae). Aust J Zool 12:362-380

Colwell RK (2009) Biodiversity: concepts, patterns, and measurement. In: Levin LA (ed) The Princeton guide to ecology. Princeton University Press, Princeton, pp 257-264. doi:10.1111/ j.1442-9993.2012.02436.x

Connel J, Slatyer R (1977) Mechanisms of succession in natural communities and their role in community stability and organization. Am Nat 111:1119-1144

Crevits H (2008) Natuurrichtplan voor de VEN-gebieden, speciale beschermingszone, groen-, park- en bosgebieden in de "Duinen van de Middenkust tussen Oostende en Blankenberge", tekstbijlage. Belgisch Staatsblad, Brussels, pp 1-69

de la Peña E, Rodríguez Echeverría S, Van Der Putten WH, Freitas H, Moens M (2006) Mechanism of control of root-feeding nematodes by mycorrhizal fungi in the dune grass Ammophila arenaria. New Phytol 169(4):829-840

de la Peña E, Bonte D, Moens M (2009) Evidence of population differentiation in the dune grass Ammophila arenaria and its associated root-feeding nematodes. Plant Soil 324:307-316 
de la Peña E, Vandomme V, Frago E (2014) Facultative endosymbionts of aphid populations from coastal dunes of the North Sea. Belg J Zool 144:41-50

De Rooij-van der Goes PCEM (1995) The role of plant-parasitic nematodes and soil-borne fungi in the decline of Ammophila arenaria (L.) Link. New Phytol 129:661-669

Evidente A, Andolfi A, Cimmino A, Ganassi S, Altomare C, Favilla M, De Cristofaro A, Vitagliano S, Sabatini MA (2009) Bisorbicillinoids produced by the fungus Trichoderma citrinoviride affect feeding preference of the aphid Schizaphis graminum. J Chem Ecol 35:533-541. doi:10.1007/s10886-0099632-6

Fornoni J (2011) Ecological and evolutionary implications of plant tolerance to herbivory. Func Ecol 25:399-407

Fraser LH, Grime JP (1999) Interacting effects of herbivory and fertility on a synthesized plant community. J Ecol 87:514-525

Haddad NM, Crutsinger GM, Gross K, Haarstad J, Knops JMH, Tilman D (2009) Plant species loss decreases arthropod diversity and shifts trophic structure. Ecol Lett 12:1029-1039. doi:10. 1111/j.1461-0248.2009.01356.x

Hågvar EB, Hofsvang T (1991) Aphid parasitoids (Hymenoptera, Aphidiidae): biology, host selection and use in biological control. Biocontrol News Inf 12:13-41

Herrier J-L, Mees J, Salman A, Seys J, Van Nieuwenhuyse H, Dobbelaere I (eds) (2005) Proceedings 'Dunes and Estuaries 2005': international conference on nature restoration practices in European coastal habitats, Koksijde, Belgium 19-23 September 2005. VLIZ Special Publication, 19. Vlaams Instituut voor de Zee (VLIZ), Oostende, pp XIV-685

Hillebrand H, Gruner DS, Borer ET, Bracken MES, Cleland EE, Elser JJ, Harpole WS, Ngai JT, Seabloom EW, Shurin JB, Smith JE (2007) Consumer versus resource control of producer diversity depends on ecosystem type and producer community structure. Proc Natl Acad Sci USA 104:10904-10909. doi:10.1073/pnas. 0701918104

Horgan FG, Stuart AM, Kudavidanage EP (2014) Impact of invasive apple snails on the functioning and services of natural and managed wetlands. Acta Oecol 54:90-100. doi:10.1016/j.actao. 2012.10.002

Huiskes AHL (1979) Biological flora of the British Isles: Ammophila arenaria (L.) link (Psamma arenaria (L.) Roem. et Shult.; Calamagrostis arenaria (L.) Roth). J Ecol 67:363-382

Huston M, Smith T (1987) Plant succession: life history and competition. Am Nat 130:168-198

Ibanez S, Bison M, Lavorel S, Moretti M (2013) Herbivore species identity mediates interspecific competition between plants. Community Ecol 14:41-47. doi:10.1556/ComEc.14.2013.1.5

Imbert E, Houle G (2001) Spatio-temporal dynamics of root mass density in a coastal dune in subarctic Quebec, Canada. J Coast Res 17:877-884

Jactel H, Brockerhoff EG (2007) Tree diversity reduces herbivory by forest insects. Ecol Lett 10:835-848. doi:10.1111/j.1461-0248. 2007.01073.x

Kaplan I, Sardanelli S, Rehill BJ, Denno RF (2011) Toward a mechanistic understanding of competition in vascular-feeding herbivores: an empirical test of the sink competition hypothesis. Oecologia 166:627-636. doi:10.1007/s00442-010-1885-9

Karlsen SR, Jepsen JU, Odland A, Ims RA, Elvebakk A (2013) Outbreaks by canopy-feeding geometrid moth cause statedependent shifts in understorey plant communities. Oecologia 173:859-870. doi:10.1007/s00442-013-2648-1

Kuijper DPJ, Jedrzejewska B, Brzeziecki B, Churski M, Jedrzejewski W, Zybura H (2010) Fluctuating ungulate density shapes tree recruitment in natural stands of the Białowieza Primeval Forest, Poland. J Veg Sci 21:1082-1098. doi:10.1111/j.1654-1103.2010. 01217.x
Lichter J (2000) Colonization constraints during primary succession on coastal Lake Michigan sand dunes. J Ecol 88:825-839

Long ZT, Mohler CL, Carson WP (2003) Extending the resource concentration hypothesis to plant communities: effects of litter and herbivores. Ecology 84:652-665

Maron JL, Crone E (2006) Herbivory: effects on plant abundance, distribution and population growth. Proc Biol Sci 273:2575-2584. doi:10.1098/rspb.2006.3587

Massad TJ (2013) Ontogenetic differences of herbivory on woody and herbaceous plants: a meta-analysis demonstrating unique effects of herbivory on the young and the old, the slow and the fast. Oecologia 172:1-10. doi:10.1007/s00442-0122470-1

Maun MA (2009) Plant communities. In: Maun MA (ed) The biology of coastal sand dunes. Oxford University Press, New York, pp 164-180

Moorleghem C (2014) Unraveling the ecology of the dune aphid Schizaphis rufula (Hemiptera: Aphidoidea): ecological preferences and parasitoids (Hymenoptera). MSc. Dissertation, Department of Biology, University of Ghent, Ghent, pp 42

Nickel H, Remane R (2002) Artenliste der Zikaden Deutschlands, mit Angabe von Nährpflanzen, Nahrungsbreite, Lebenszyklus, Areal und Gefährdung (Hemiptera, Fulgoromorpha et Cicadomorpha). Beiträge zur Zikadenkunde 5:27-64

Nieto Nafría JM (2007) Fauna Europaea: Hemiptera, Aphidoidea. Fauna Europaea version 1.3. http://www.faunaeur.org. Accessed 15 May 2014

Pettersson J (1971a) Studies on four grass-inhabiting species of Schizaphis (Hem. Aphidoidea) with special reference to sex habits of $S$. arrhenatheri Pettersson. Dissertation, Swedish University of Agricultural Sciences

Pettersson J (1971b) Studies on four grass-inhabiting species of Schizaphis (Hem. Aphidoidea): I. Literature review. Ent Scand 2:67-73

Pettersson J (1971c) Studies on four grass-inhabiting species of Schizaphis (Hom.: Aph.): III. (a) host plants. Swed J Agric Res 1:133-138

Pimentel D (1961) Species diversity and insect population outbreaks. Ann Entomol Soc Am 54:422-437

Provoost S, Feys S, Van Gompel W, Vercruysse W (2011a) Evaluatie van het gevoerde beheer en opmaak van een beheerplan voor het VNR De Duinen en Bossen van De Panne. Deel I: Evaluatie van het gevoerde beheer in de deelgebieden Houtsaegerduinen en de Westhoek. Rapporten van het Instituut voor Natuur- en Bosonderzoek 53, Instituut voor Natuur- en Bosonderzoek, Brussel, pp 123

Provoost S, Jones MLM, Edmondson SE (2011b) Changes in landscape and vegetation of coastal dunes in northwest Europe: a review. J Coast Conserv 15:207-226

Root RB (1973) Organization of a plant-arthropod association in simple and diverse habitats: the fauna of collards (Brassica Oleracea). Ecol Monogr 43:95-124. doi:10.2307/1942161

SAS Institute Inc (2014) SAS/STAT ${ }^{\circledR} 9.4$ user's guide. SAS Institute Inc, Cary, pp 272

Schmitz OJ (2008) Herbivory from individuals to ecosystems. Annu Rev Ecol Evol Syst 39:133-152. doi:10.1146/annurev.ecolsys. 39.110707.173418

Stam JM, Kroes A, Li Y, Gols R, van Loon JJA, Poelman EH, Dicke M (2014) Plant interactions with multiple insect herbivores: from community to genes. Annu Rev Plant Biol 65:689-713. doi:10.1146/annurev-arplant-050213-035937

Starý P (1987) Subject bibliography of aphid parasitoids (Hymenoptera: Aphidiidae) of the world 1758-1982. Monogr Appl Entomol 25:101

Stein C, Unsicker SS, Kahmen A, Wagner M, Audorff V, Auge H, Prati D, Weisser WW (2010) Impact of invertebrate herbivory in 
grasslands depends on plant species diversity. Ecology 91:1639-1650. doi:10.1890/09-0600.1

Strauss SY, Agrawal AA (1999) The ecology and evolution of plant tolerance to herbivory. Trends Ecol Evol 14:179-185. doi:10. 1016/S0169-5347(98)01576-6

Tariq M, Wright DJ, Rossiter JT, Staley JT (2012) Aphids in a changing world: testing the plant stress, plant vigour and pulsed stress hypotheses. Agric For Entomol 14:177-185. doi:10.1111/j. 1461-9563.2011.00557.x

Turpeau E, Hullé M, Chaubet B (2013) Caractères généraux des cycles. Encyclop'Aphid. https://www6.inra.fr/encyclopediepucerons/Qu-est-ce-qu-un-puceron/Cycles-biologiques. Accessed 22 April 2014

Unsicker SB, Baer N, Kahmen A, Wagner M, Buchmann N, Weisser WW (2006) Invertebrate herbivory along a gradient of plant species diversity in extensively managed grasslands. Oecologia 150:233-246. doi:10.1007/s00442-006-0511-3

van der Putten WH, Troelstra SR (1990) Harmful soil organisms in coastal foredunes involved in degeneration of Ammophila arenaria and Calammophila baltica. Can J Bot Rev Can Bot 68:1560-1568

van der Putten WH, Breteler JTV, Van Dijk C (1989) Colonization of the root zone of Ammophila arenaria by harmful soil organisms. Plant Soil 120:213-223

Van der Stoel CD, van der Putten WH, Duyts H (2002) Development of a negative plant-soil feedback in the expansion zone of the clonal grass Ammophila arenaria following root formation and nematode colonization. J Ecol 90:978-988

Van der Stoel CD, Duyts H, van der Putten WH (2006) Population dynamics of a host-specific root-feeding cyst nematode and resource quantity in the root zone of a clonal grass. Oikos 112:651-659

van Veen FJF, Morris RJ, Godfray HCJ (2006) Apparent competition, quantitative food webs, and the structure of phytophagous insect communities. Annu Rev Entomol 51:187-208

Vandegehuchte ML, de la Peña E, Bonte D (2010a) Relative importance of biotic and abiotic soil components to plant growth and insect herbivore population dynamics. PLoS ONE 5:e12937. doi:10.1371/journal.pone.0012937

Vandegehuchte ML, de la Peña E, Bonte D (2010b) Aphids on Ammophila arenaria in Belgium: first reports, phenology and host range expansion. Belg J Zool 140:77-80

Vandegehuchte ML, de la Peña E, Bonte D (2010c) Interactions between root and shoot herbivores of Ammophila arenaria in the laboratory do not translate into correlated abundances in the field. Oikos 119:1011-1019. doi:10.1111/j.1600-0706.2009. 18360.xVan

Weeda EJ, Westra R, Westra C, Westra T (2003) Nederlandse oecologische flora: wilde planten en hun relaties $5 . \mathrm{KNNV}$ Uitgeverij/IVN, Zeist, p 400 